\title{
Biodiesel Production from Waste Cooking Oil
}

\author{
Carlos A. Guerrero F., Andrés Guerrero-Romero and Fabio E. Sierra \\ National University of Colombia, \\ Colombia
}

\section{Introduction}

Biodiesel refers to all kinds of alternative fuels derived from vegetable oils or animal fats. The prefix bio refers to renewable and biological nature, in contrast to the traditional diesel derived from petroleum; while the diesel fuel refers to its use on diesel engines. Biodiesel is produced from the triglycerides conversion in the oils such as those obtained from palm oil, soybean, rapeseed, sunflower and castor oil, in methyl or ethyl esters by transesterification way. In this process the three chains of fatty acids of each triglyceride molecule reacts with an alcohol in the presence of a catalyst to obtain ethyl or methyl esters.

The ASTM (American Society for Testing and Materials Standard) describes the biodiesel as esters monoalkyl of fatty acids of long chain that are produced from vegetable oil, animal fat or waste cooking oils in a chemical reaction known as transesterification.

Biodiesel has the same properties of diesel used as fuel for cars, trucks, etc. This may be mixed in any proportion with the diesel from the oil refined. It is not necessary to make any modifications to the engines in order to use this fuel.

"The use of pure biodiesel can be designated as B100 or blended with fuel diesel, designated as BXX, where XX represents the percentage of biodiesel in the blend. The most common ratio is B20 which represents a $20 \%$ biodiesel and $80 \%$ diesel" (Arbeláez \& Rivera, 2007 pp 4). Colombia in South America, is taking advantage of the opportunities that biofuels will open to the agriculture. With more than a million liters a day, Colombia is the second largest producer of ethanol in Latin America, after Brazil. This has decongested the domestic market of sugar at more than 500 thousand tons. The result is strong revenue for the 300,000 people who derive their livelihood from the production of panela (from sugar cane).

In Colombia the biodiesel is produced from the palm oil and methanol, "being the last imported to meet the demand in the biodiesel production". In the past two years, the biodiesel production from Palm was between 300000 liters/day to 965000 liters per day, distributed in four plants located in the Atlantic coast and in the country center.

In the biodiesel production is technically possible to use methanol and ethanol alcohol (Cujia \& Bula, 2010. pp 106).

The palm oil is one of oilseeds trade more productive on the planet; it is removed between six and ten times more oil than the other as soy, rapeseed and sunflower. Colombia has more than 300,000 hectares planted in Palm oil, generating permanent and stable employment for more than 90,000 people. 
The biodiesel advantages are that it is a renewable and biodegradable biofuel; it produces less harmful emissions to the environment than those that produce fossil fuels. Specifically the Palm biodiesel pure or mixed with diesel fuel reduces the emissions of $\mathrm{CO}_{2}$, nitrogen oxides (NOx) and particulate material. Table 1, shows the world production of vegetable oils.

\begin{tabular}{|c|c|}
\hline OILS & MILLION TONS \\
\hline Palm oil (fruit) & 43.20 \\
\hline Soy oil & 38.11 \\
\hline Rapeseed oil & 19.38 \\
\hline Sunflower oil & 11.45 \\
\hline Cotton oil & 4.94 \\
\hline Palm oil (seed) & 5.10 \\
\hline Peanut oil & 4.93 \\
\hline Coconut oil & 3.62 \\
\hline Olive oil & 2.97 \\
\hline
\end{tabular}

Table 1. World production of vegetable oils, 2008/2009. (Source: “Oilseeds: World markets and trade". FAS-USDA, October 2008)

The estimated consumption of diesel in the world at the end of the year 2005 was 960 billion liters. On the other hand, the production of biodiesel during the same year was 4.2 billion liters (Figure 1). For example, assuming that $2 \%$ of diesel was replaced with biodiesel, it would mean an increase of 15 billion liters in the biodiesel global production. This amount of biodiesel has other impacts, including overproduction of glycerin, the use of more land, etc.

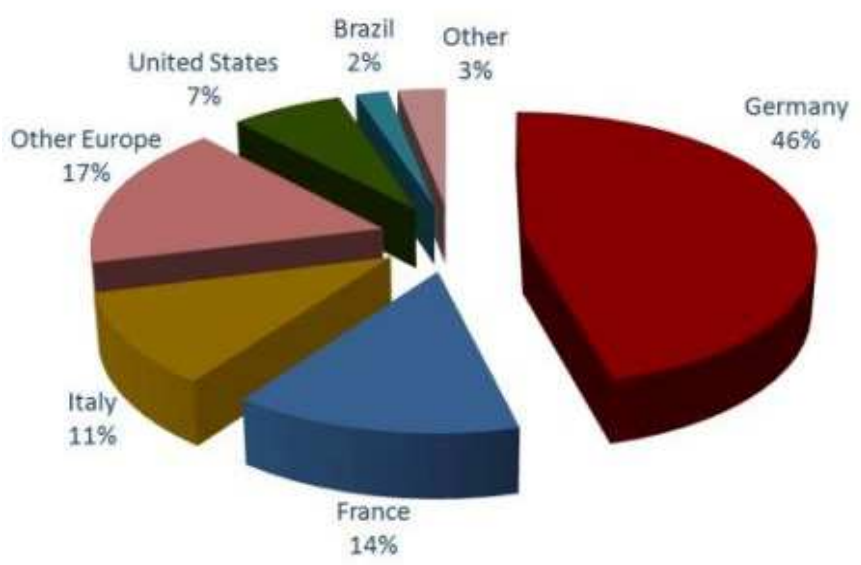

Fig. 1. World production of biodiesel (Source: National Federation of Oil Palm Growers (FEDEPALMA)).

ASTM has specified different fuel tests needed to ensure their proper functioning.

Table 2, lists the specifications established for biodiesel and the corresponding test method. 


\begin{tabular}{|c|c|c|c|c|}
\hline \multirow{2}{*}{ FEATURES } & \multirow{2}{*}{ UNIT } & \multicolumn{2}{|l|}{ LIMITS } & \multirow{2}{*}{ TEST METHOD } \\
\hline & & Minimum & Maximum & \\
\hline Ester content & $\%(\mathrm{~m} / \mathrm{m})$ & 96.5 & - & EN 14103 \\
\hline Density a $15^{\circ} \mathrm{C}$ & $\mathrm{Kg} / \mathrm{m}^{2}$ & 860 & 900 & $\begin{array}{l}\text { EN ISO } 3675 \text { EN ISO } \\
12185\end{array}$ \\
\hline Viscosity a $40^{\circ} \mathrm{C}$ & $\mathrm{Mm}^{2} / \mathrm{g}$ & 3.50 & 5.00 & EN ISO 3104 \\
\hline Flash point & ${ }^{\circ} \mathrm{C}$ & 120 & - & Pr EN ISO 3679 \\
\hline Sulfur content & $\mathrm{mg} / \mathrm{kg}$ & - & 10.0 & $\begin{array}{l}\text { PrEN ISO } 20846 \text { pr } \\
\text { EN ISO } 20884\end{array}$ \\
\hline $\begin{array}{l}\text { Carbon residue ( in } 10 \% \text { of } \\
\text { distilled residue) }\end{array}$ & $\%(\mathrm{~m} / \mathrm{m})$ & - & 0.30 & EN ISO 10370 \\
\hline Cetane index & & 51.0 & & EN ISO 5165 \\
\hline Sulphated ash content & $\%(\mathrm{~m} / \mathrm{m})$ & - & 0.02 & ISO 3987 \\
\hline Water content & $\mathrm{mg} / \mathrm{kg}$ & - & 500 & EN ISO 12937 \\
\hline Total contamination & $\mathrm{mg} / \mathrm{kg}$ & - & 24 & EN 12662 \\
\hline $\begin{array}{l}\text { Cooper band corrosion }(3 \mathrm{~h} \\
\left.\text { at } 50^{\circ} \mathrm{C}\right)\end{array}$ & Classification & Class 1 & & EN ISO 2160 \\
\hline Oxidation stability $110^{\circ} \mathrm{C}$ & Hours & 6.0 & & EN 14122 \\
\hline Acid index & $\mathrm{mg} \mathrm{KOH} / \mathrm{g}$ & & 0.50 & EN 14111 \\
\hline Iodine index & $\begin{array}{l}\text { g de iodine/ } \\
100 \mathrm{~g}\end{array}$ & & 140 & EN 14103 \\
\hline $\begin{array}{l}\text { Methyl ester of linoleic } \\
\text { acid }\end{array}$ & $\%(\mathrm{~m} / \mathrm{m})$ & & 12.0 & EN 14103 \\
\hline $\begin{array}{l}\text { Methyl esters of } \\
\text { methylpoli-unsaturated (> } \\
=4 \text { double bonds) }\end{array}$ & $\%(\mathrm{~m} / \mathrm{m})$ & & 1 & \\
\hline Methanol content & $\%(\mathrm{~m} / \mathrm{m})$ & & 0.20 & EN 14110 \\
\hline Monoglycerides content & $\%(\mathrm{~m} / \mathrm{m})$ & & 0.80 & EN 14105 \\
\hline Diglycerides content & $\%(\mathrm{~m} / \mathrm{m})$ & & 0.20 & EN 14105 \\
\hline Triglycerides content & $\%(\mathrm{~m} / \mathrm{m})$ & & 0.20 & EN 14105 \\
\hline Free glycerin & $\%(\mathrm{~m} / \mathrm{m})$ & & 0.20 & EN 14105 EN 14105 \\
\hline Total glycerin & $\%(\mathrm{~m} / \mathrm{m})$ & & 0.25 & EN 14105 \\
\hline Metals of group $1(\mathrm{Na}+\mathrm{K})$ & $\mathrm{mg} / \mathrm{kg}$ & & 5.0 & EN 14108 EN 14109 \\
\hline Metals of group $2(\mathrm{Ca}+\mathrm{Mg})$ & $\mathrm{mg} / \mathrm{kg}$ & & 5.0 & PrEN 14538 \\
\hline Phosphorus content & $\mathrm{mg} / \mathrm{kg}$ & & 10.0 & EN 14107 \\
\hline
\end{tabular}

Table 2. ASTM Features

\subsection{Environmental problems for disposing used cooking oil}

Used cooking oil causes severe environmental problems, "a liter of oil poured into a water course can pollute up to 1000 tanks of 500 liters". It's feasible to demonstrate the contamination with the dumping of these oils to the main water sources.

The oil which reaches the water sources increases its organic pollution load, to form layers on the water surface to prevent the oxygen exchange and alters the ecosystem. The dumping of the oil also causes problems in the pipes drain obstructing them and creating odors and increasing the cost of wastewater treatment. For this reason, has 
been necessary to create a way to recover this oil and reuse it. Also due to the wear and tear resulting in sewer pipes may cause overflows of the system, "generating diseases that can cause mild stomach cramps to diseases potentially fatal, such as cholera, infectious hepatitis and gastroenteritis, due to the sewage contains water which can transport bacteria, viruses, parasites, intestinal worms and molds" (Peisch. Consulted: http://www.seagrantpr.org/catalog/files/fact_sheets/54-aguas-usadas-de-PR.PDF). The dangerous odors generate impact negatively on health, "is formed hydrogen sulfide $\left(\mathrm{H}_{2} \mathrm{~S}\right)$, which can cause irritation of the respiratory tract, skin infections, headaches and eye irritation" (Peisch. Consulted: http://www.seagrantpr.org/ catalog/files/fact_sheets/54aguas-usadas-de-PR.PDF).

\section{Types of cooking oil}

Among the alternatives as a vegetal raw material to extract the oil are: oil palm, soybean, sesame, cotton, corn, canola, sunflower and olives.

\subsection{Palm oil}

Palm oil is retrieved from the mesocarp of the Palm fruit, this oil is regarded as the second most widely produced only surpassed by the soybean oil. The oil palm is a tropical plant characteristic of warmer climates that grows below 500 meters above sea level. "Its origin is located in the Guinea Gulf in West Africa." "Hence its scientific name, Elaeis guineensis Jacq and its popular name: African oil palm" (FEDEPALMA. Consulted: http://www.fedepalma.org/palma.htm).

Colombia is the largest producer of palm oil in Latin America and the fourth in the world. "The extracted oil from the palm contains a relationship 1:1 between saturated and unsaturated fatty acids, is also a major source of natural antioxidants as tocopherols, tocotrienols and carotenes"(FEDEPALMA. Consulted: http://www.fedepalma.org/ palma.htm). It has been proven that Palm oil is natural source vitamin $\mathrm{E}$, in the form of tocopherols and tocotrienols. The tocotrienol act as protectors against cells aging, arthrosclerosis, cancer and some neurodegenerative diseases such as Alzheimer's disease. Unrefined palm oil is the richest in beta-carotene natural source; its consumption has proved to be very useful for preventing and treating the deficiency of vitamin A in risk populations.

\subsubsection{Characteristics of plant}

The oil palm presents fruit by thousands, spherical, ovoid or elongates, to form compact clusters of between 10 and 40 kilograms of weight. Inside, they kept a single seed, almonds or palmist, to protect with the fart, a woody endocarp, surrounded in turn by a fleshy pulp. Both, pulp and almond oil generously provide. The productive life of the oil palm can be most of fifty years, but from the twentieth or twenty-five the stem reaches a height that hinders the work of harvest and marks the beginning of the renewal in commercial plantations. 25 to $28^{\circ} \mathrm{C}$ on average monthly temperatures are favorable, if the minimum average temperature is below $21^{\circ} \mathrm{C}$. Temperatures of $15^{\circ} \mathrm{C}$ stop the growth of the seedlings from greenhouse and decrease the performance of adult palms. Between 1,800 and 2,200 $\mathrm{mm}$ precipitation is optimal, if it is well distributed in every month. Like the coconut palm, the palm oil is favored by deep, loose and well drained soils. A superficial phreatic level limits the development and nutrition of roots. In general, the 
physical characteristics good, texture and structure, are preferable to the level of fertility, as it can be corrected with mineral fertilization. The palm oil resists low acidity levels, up to $\mathrm{pH} 4$. Too alkaline soils are harmful. Although you can plant with success on land of hills with slopes above of $20^{\circ}$, are preferred levels or slightly wavy, with no more than $15^{\circ}$ gradients.

\subsubsection{Pests}

The major pest of palm oil and its damage are:

- Acaro: They are located on the underside of the leaves, mainly in vivarium palms. The damages are identified by the discoloration of the leaves, which reduces the photosynthetic area. We can fight it with Tedión.

- Arriera ant: it is common in tropical areas. This animal can cause serious defoliations in palms of all ages. We can fight it with bait poisoned as Mirex, applied to the nest mouths.

- Estrategus: Is a beetle of 50 to $60 \mathrm{~mm}$ long, black, with two horns. This animal drills in the ground, at the foot of the Palm, a gallery of even $80 \mathrm{~cm}$; penetrates the tissues of the trunk base and destroys it. It is controlled with $200 \mathrm{~g}$ of heptachlor powdered $5 \%$, slightly buried around the Palm.

- Rats: This animal can cause damage at the trunk base of young palms. Controlled with baits of coumarine, which must be changed regularly.

- Yellow beetle or alurnus: attacks the young leaves of the plant heart as well as on the coconut tree. It is controlled with sprayings of Thiodan 35 EC, solution of $800 \mathrm{cc}$ in 200 liters of water. Apply 2 to 4 liters in palm.

- Beetles or black palm weevil: In Palm oil causes the same damage to the coconut palm.

- Lace bug: is $2.5 \mathrm{~mm}$ long. It is an insect of transparent grey color. It is located in the underside of the leaves. Their stings favor infections by various fungi, which may cause draining of the leaves.

\subsection{Rapeseed or canola oil}

Rapeseed is a "specie oilseed in the cruciferous family. Many of the species of this family have been cultivated since long time ago that their roots, stems, flowers and seeds are edible" (Iriarte, Consulted: http://www.inta.gov.ar/ediciones/idia/oleaginosa /colza01.pdf). Ideally grows in climates that go from temperate to slightly cold and wet (minimum of $0{ }^{\circ} \mathrm{C}$ and maximum of $40^{\circ} \mathrm{C}$ ). When the seeds of rapeseed are crushed we can obtain oil and a kind of pulp or prized residue from always to feed livestock, since that gives a $34 \%$ protein and $15 \%$ crude fiber. The biodegradable properties of rapeseed or canola oil make it ideal to be used on the basis of paints, herbicides, lubricants, food packaging, etc.

\subsubsection{Characteristics of plant}

Oilseed rape (Brassica napus) is a crucifer of deep and pivoting root. The stem has a size of $1.5 \mathrm{~m}$ approximately. The lower leaves are petiolate but the superiors entire and lanceolate. The flowers are small, yellow, and are grouped in terminal racemes. The fruits have a number of grains by pod around 20-25, depending on the variety. The rapeseed composition is showed in the table 3 : 


\begin{tabular}{|l|l|}
\hline COMPOSITION & $\%$ \\
\hline Proteins & 21,08 \\
\hline Fat & 48,55 \\
\hline Fiber & 6,42 \\
\hline Ashes & 4,54 \\
\hline Nitrogen-free extracts & 19,41 \\
\hline TOTAL & 100,00 \\
\hline
\end{tabular}

Table 3. Rapeseed composition.

The seeds are spherical of 2 to $2.5 \mathrm{~mm}$ in diameter and when are mature have a reddish or black brown color. Rapeseed has a proportion (39\%) of oil where there are a large number of fatty acids of long-chain, which quantitatively the most important is the erucic acid. The cultivation of rapeseed has ability to grow in temperate climates to temperate cold with good humidity. It adapts to different soil types, the ideals are the franc soils of good fertility and permeable which is a very sensitive crop to the superficial flooding.

\subsubsection{Pests}

- Rape stem weevil (Ceuthorrhynchus napi): the grub of this insect deforms the stem of the rape, which is curved and often indenting in a certain length.

- Terminal bud Weevil (Ceuthorrhynchus picitarsis): adults do not cause damage, but the larvae destroy the terminal bud and force the plant to produce side shoots. The treatments are made with endosulfan and Fosalón.

- The siliques weevil (Ceuthorrhynchus assimilis): adults bite the young siliques and the larvae gnaw seeds causing a significant decrease in the harvest. Endosulfan and Fosalón are used in treatments.

- Cecydomia (Dasyneura brassiceae): The larvae of this insect destroy the siliques totally. The endosulfan and fosalon control this plague.

- Meligetos of the cruciferous (Meligethes sp): adults are in charge of gnawing the buttons of the rapeseed; these attacks are more important younger are the buttons. When begin the flowering the damage decrease.

- Flea of rapeseed (Psyllodes chrysocephala): adults appear in autumn rape fields, generally shortly after birth gnawing the leaves and can destroy large number of plants. Karate to doses of $40-80 \mathrm{cc} / \mathrm{hL}$ is recommended for the treatment.

- Flea of the cabbage (Phylotreta sp): adult insects wintering in the soil in September and appear in April. Karate works very well against these insects.

\subsection{Sunflower oil}

The oil extracted from sunflower seeds is considered to be of high quality for a low percentage of saturated fatty acids and a high percentage of unsaturated fatty acids. It also contains essential fatty acids and a considerable amount of tocopherols that gives it stability. The acidic composition of the sunflower depends on the genotype and the environment. There are currently three groups of genotypes: traditional, oleic medium and oleic high.

\subsubsection{Characteristics of plant}

The sunflower belongs at the family "Asteraceae, whose scientific name is Helianthus annuus. It is an annual plant with a vigorous development in all its organs. Within this species there 
are many types or subspecies grown as ornamental plants, oilseeds and forage plants" (INFOAGRO, Consulted: http://www.infoagro.com/herbaceos/oleaginosas / girasol.htm ). Average sunflower cycle includes between 100 and 150 days according to genotypes, dates of planting, latitude and availability of water and nutrients. The "temperature is the most important factor in the control of the seeds germination being the optimal near to $26^{\circ} \mathrm{C}$ with maximum temperatures of $40{ }^{\circ} \mathrm{C}$ and minimum from 3 to $6^{\circ} \mathrm{C}$. The threshold for soil temperature $\left(0\right.$ to $5 \mathrm{~cm}$ ) from which normally starts sowing is between 8 and $10^{\circ} \mathrm{C}^{\prime \prime}$ (DiazZorita et al, Consulted: http://www.asagir.org.ar /Publicaciones/cuadernillo_web.pdf). The availability of water acts on the soaking of seeds, on the subsequent growth of the seedling. The water excess decreases the amount of air in the soil.

\subsubsection{Pests}

Pests of early-onset (e.g. cutting caterpillars, leafcutter ants, velvety larvae, worm wire, tenebrionido of the sunflower, underground grille, weevils, black beetle, slugs, etc.) produce damage in seeds and seedlings. Slugs cause great damage to the leaves. The control is convenient with treatments of seeds or specific toxic baits.

\section{Biodiesel production process}

The biodiesel production is given by the transesterification reaction which consists of three consecutive and reversible reactions. First, the triglyceride is converted in diacylglycerol, and running at monoglyceride and glycerin. In each reaction one mole of methyl ester is released as shown in Figure 2.

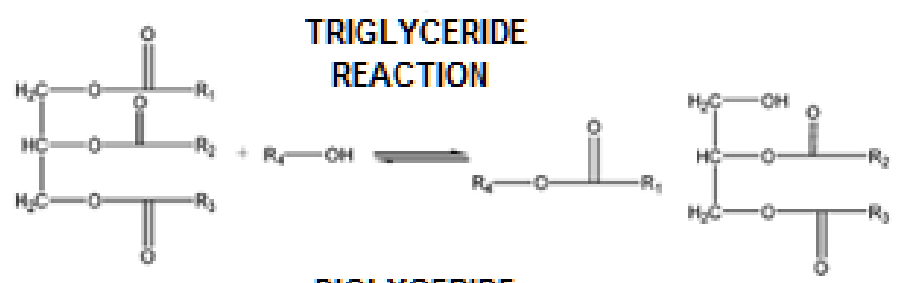

DIGLYCERIDE

REACTION
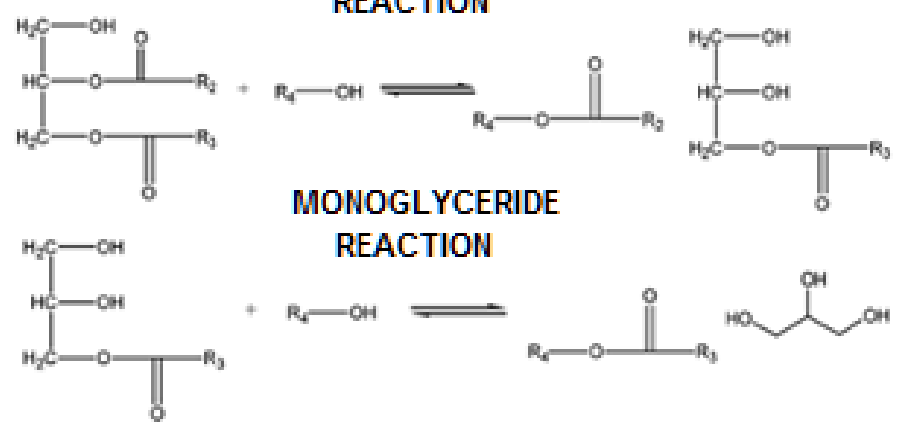

Fig. 2. Stages of the transesterification reaction (Arbeláez \& Rivera, 2007. pp 13) 
Figures 3 and 4 show the secondary reactions that may occur: the saponification reaction and the neutralization reaction of free fatty acids.

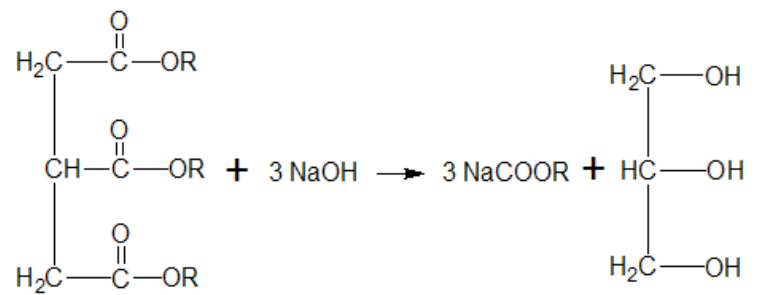

Fig. 3. Saponification reaction (Arbeláez \& Rivera, 2007. pp 13)

$$
\begin{aligned}
& \mathrm{RCOOH}+\mathrm{NaOH} \rightarrow \mathrm{R}-\mathrm{COONa}+\mathrm{H}_{2} \mathrm{O} \\
& \text { Fatty acid Sodium carboxylate }
\end{aligned}
$$

Fig. 4. Neutralization reactions of free fatty acids (Arbeláez \& Rivera, 2007. pp 13)

\subsection{Raw materials}

The biodiesel production comes mostly from oils extracted oilseed plants especially sunflower, soy, rapeseed and animal fats. However, any material that contains triglycerides can be used for the biodiesel production. "In addition to the oil or fat is needed an alcohol and catalyst to convert oils and fats in alkyl esters". (Arbeláez \& Rivera, 2007. pp7)

\subsubsection{Alcohol}

"Primary and secondary alcohols with string of 1-8 carbons are used for the biodiesel production, among the alcohols that can be used in this process are: methanol, ethanol" (Cujia \& Bula, 2010. pp 106), propanol y butanol. "When are used alcohols such as ethanol is more complicated the recovery of pure alcohol in the process because the azeotrope that forms with water"(Cheng et al. 2008. pp 4) and the performance of ethyl esters is less compared to the methyl esters due methanol has a lower molecular weight $(32.04 \mathrm{~g} / \mathrm{mole})$ compared to ethanol (46.07 g/mole)."On the other hand if you use methanol, not would contribute to environmental issues and sustainability, biodiesel would not be completely bio, by having a fossil component provided by the alcohol, because methanol is made from natural gas, which is fossil" "(Cheng et al. 2008. pp 4).To use methanol or ethanol is needed "a mechanical agitation to encourage the transfer of mass"(Arbeláez \& Rivera, 2007. pp 10)."In the course of the reaction form emulsions, using methanol is easy and quickly dissolved, forming a glycerol-rich bottom layer and a higher layer in methyl esters, while using ethanol these emulsions are more stable making the process of separation and purification of ethyl esters more difficult"(Arbeláez \& Rivera, 2007. pp 10).

Is preferred to use methanol in the biodiesel production because of their low viscosity $\left(0.59 \mathrm{~m} * \mathrm{~Pa} * \mathrm{~s}\right.$ at $\left.20^{\circ} \mathrm{C}\right)$, because using alcohols such as ethanol with high viscosity $\left(1,074 \mathrm{~m} * \mathrm{~Pa}{ }^{*} \mathrm{~s}\right.$ at $\left.20^{\circ} \mathrm{C}\right)$, the biodiesel viscosity increases and as a result a "fuel of high 
viscosity not will be pulverized properly by injection systems that have diesel engines. Also increase the opacity of fumes which limits their application in automotive engines"(Benjumea et al. 2007. pp 149).

In the reaction performance is feasible to reach "higher conversions with methanol, ethanol using the process is more complex, expensive, requires a higher consumption of energy and time"(EREN. 2003.pp 38). "We found that it requires less reaction time when using methanol rather than ethanol, either in acid or alkaline catalysis, reaching high yields"(Giron et al. 2009.pp 18).

With the above, the methanol is selected to be used in the biodiesel production due to its lower cost, better performance and less time and energy during the reaction.

\subsubsection{Catalysts}

Homogeneous, heterogeneous or enzyme catalysts are used in the biodiesel production. Homogeneous catalysts are soluble in the middle of reaction, i.e. they are in a single phase either liquid or gaseous. "One of the advantages of homogeneous catalysis is the high speed of reaction, and moderate temperature and pressure conditions" (EREN. 2003.pp 4). The catalysts can be acids or alkalis, the acid catalysts are effective but require a time interval extremely long and temperatures exceeding $100{ }^{\circ} \mathrm{C}$ for its action. "Getting conversions of $99 \%$ with a concentration of $1 \%$ sulfuric acid in relation to the amount of oil, it takes about 50 hours" "(EREN. 2003.pp 13). We can use this catalytic process when the oils have a high degree of acidity and "harm the action of alkali catalysts with acidity greater than 10 \%"(EREN. 2003.pp 39).We can use sulfuric acid $\left(\mathrm{H}_{2} \mathrm{SO}_{4}\right)$, phosphoric acid $\left(\mathrm{H}_{3} \mathrm{PO}_{4}\right)$, among others. When is used "acid catalysts with alcohol excess is that the recovery of glycerin is more difficult as the quantities of alcohol are quite large compared to other type of catalyst" (Arbeláez \& Rivera, 2007. pp13).

"Using $\mathrm{HCl}$ are achieved yields of $61 \%$ and with $\mathrm{H}_{2} \mathrm{SO}_{4}$ we can obtain $80 \%$ "(Liu et al. 2006a pp 186), but these "catalysts are more corrosive than alkali catalysts"(Errazu et al. 2005 pp 1305). In comparison with the acidic catalysts, the basic catalysts accelerate the reaction rate, the disadvantage of basic catalysts is that produces soaps due to the high amounts of free fatty acids and water by which we must add the appropriate amount of base to neutralize fatty acids free. The most commonly used are sodium hydroxide $(\mathrm{NaOH})$, potassium hydroxide $(\mathrm{KOH})$ and inappropriate for industrial application $\left(\mathrm{CH}_{3} \mathrm{ONa}\right)$ sodium methoxide since this is more expensive and "requires total absence of water" (EREN. 2003 pp 40). "The catalysts are dissolved in the reaction mixture alcohol-oil what does that not can be recovered at the end of the transesterification reaction" (Arbeláez \& Rivera, 2007. pp13). "By using $\mathrm{KOH}$ as a catalyst we can produce potassium fertilizers such as potassium chloride, potassium sulphate and potassium nitrate if the product with phosphoric acid is neutralized" (Arbeláez \& Rivera, 2007. pp14).

"The maximum yield found with $\mathrm{NaOH}$ is $85 \%$ at a sodium hydroxide concentration of $1,0 \%$. Adding an excess in the amount of the catalyst, it gives rise to the formation of an emulsion which increases viscosity and leads to the gel formation" "(Cheng et al. 2008. pp 2210). "With regard to the use of catalyst as $\left(\mathrm{NaOCH}_{3}\right)$ sodium methoxide and $\left(\mathrm{KOCH}_{3}\right)$ potassium methoxide we can observe high efficiency compared with other alkali catalysts"(Cheng et al. 2008. pp 2210). The temperature of the transesterification reaction "should not exceed the boiling point of alcohol, because it vaporizes and forms bubbles which limit the reaction in the interfaces alcohol/oil/biodiesel"(Giron et al. 2009.pp 18) 
"To be used as catalyst $\mathrm{NaOH}$ with methanol, has been found that the optimum temperature to achieve high yields was $60^{\circ} \mathrm{C}$, while using $\mathrm{KOH}$ to this same temperature not achieved such high yields and higher catalyst concentrations should be used to using $\mathrm{NaOH}^{\prime}$ (Liu et al. 2006b pp 110). "In an alkali catalyzed process is reached high purity and yields in short periods of time ranging between 30 - 60 minutes" (Liu et al. 2006a pp 186).

Heterogeneous catalysts are found in two phases and a contact area, "the use of these catalysts simplifies and makes more economical the purification process due the easy separation of the products and reactants. The disadvantage is the difficulty to temperature control for very exothermic reactions, limitations on mass transfer of reactants and products, as well as high mechanical resistance to the catalyst" (Arbeláez \& Rivera, 2007. pp12). Among the most common catalysts are the metal oxides $(\mathrm{MgO}, \mathrm{CaO})$, acids of Lewis $\left(\mathrm{SnCl}_{2}\right)$, etc. For example, by using zinc oxide are obtained yields of $50.7 \%$, when using $\mathrm{Al}_{2} \mathrm{O}_{3}$ is obtained $57.5 \%$ and using $\mathrm{CaO}$ yield of $65 \%$ "(Rojas \& Torres. 2009 pp 15). "These catalysts have limitations on transfer of mass of reactants and products" (Arbeláez \& Rivera, 2007. pp12), but they have the advantage that they are not corrosive to the reactor"(Guan et al. 2009 pp 520). The easy separation of the products generates a "simplification of the manufacturing process since the catalyst can be separate from the products of reaction with a simple filtration process"(Lles et al. 2008 pp 63). "Don't generate byproduct of soap by reaction with free fatty acids (AGL)". (Bournay et al. 2005. pp 191) "Using $\mathrm{CaO}$ is achieved a yield of $65 \%$ and by using $\mathrm{MgO}$ a yield of 64\%"(Bournay et al. 2005. pp 192). To achieve high yields the reaction must be carried out "to a higher temperature increasing energy costs" (Bournay et al. 2005. pp 191).Reported high reaction times, because the "speed of transesterification reaction with these catalysts is lower in comparison with homogeneous catalysts, due to the mass transfer resistance" (Guan et al. 2009 pp 522).

Finally, the lipases being effective for the transesterification reaction can be used between the enzyme catalysts. "This type of catalysis has the advantage of allowing the use of alcohol with high content of water (more than 3\%), low temperatures, which is an energy-saving and high degrees of acidity in oils" (EREN. 2003. pp 41).

\subsubsection{Waste cooking oil}

The waste cooking oil is generated from the fried food, which need large amounts of oil because it requires the full immersion of food at temperatures greater than $180{ }^{\circ} \mathrm{C}$. Accordingly to the high temperatures are generated changes in its chemical and physical composition, as well as in its organoleptic properties which affect both the food and oil quality.

Reuse of domestic oil has a high risk to the health of consumers as depending on the type of food subjected to frying, "this absorbs between $5 \%$ and $20 \%$ of the used oil, which can increase significantly the amount of hazardous compounds that provide degraded oil to food" (EREN. 2003. pp 31). "In an alkali catalyzed process is reached high purity and high yields in short periods of time ranging between $30-60$ minutes"(Liu et al. 2006 pp 186).

Used cooking oil is normally black, a strong odor and does not have large amount of solids because its collection is passed through a fine mesh. In Figure 5, we can see a sample of used oil from the hotel sector. 


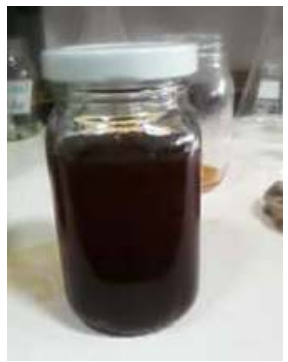

Fig. 5. Sample of waste cooking oil

\subsubsection{Domestic waste oil treatment}

Wastes containing these types of oils are products of decomposition that impair the oil quality causing reduction in productivity in the transesterification reaction and may also generate undesirable by-products which hurt the final product. For these reasons, it is important to refine the waste domestic oil for the biodiesel production. "This type of refinement has a right effect on the yield of the reaction from $67 \%$ to $87 \%$ after bleaching". (EREN. 2003. pp 36). For the treatment of adequacy of waste domestic oil, the operations that can be applied are filtration, de-acidification or neutralization and whitening. The processes of degumming and deodorization aren't needed because the oils have already been treated prior to use and although during degradation odors occur, the removal is not essential for the biodiesel production.

- Filtration. The operation is for removing solids, inorganic material, and other contaminants in the oil. It can be carried out at temperatures higher than $60^{\circ} \mathrm{C}$, where substances carbonaceous produced from burnt organic material, pieces of paper, waste food and other solids are removed or occur at low temperatures which depend on the physical condition of the oil. In addition, we can delete solid fats or products of low melting points from the frying process.

- Desacidification It is the process by which free oils fatty acids are removed, various methods are used:

a. Neutralization with alkaline solution: in this process the acids are removed in the form of soaps.

b. Esterification with glycerin: seeks to regenerate the triglyceride.

c. Extraction by solvents: where it is used ethanol in proportions 1.3 times the amount of oil.

d. The distillation of fatty acids, this method requires a high energy cost.

e. Removal of fatty acids with ion-exchange: a resin of strongly basic character for the removal of free fatty acids and the color of the oil is used.

Method that provides greater account of productivity in the removal of free fatty acids is the neutralization by caustic soda, since it not only are obtained high relations, but also helps in the bleaching of the oil, because made soaps help dragging the color generators. There are basically two procedures:

- Neutralization with dilute alkali: are used concentrations of 0.75 to $2 \mathrm{~N}$.

- Neutralization with concentrated alkali, where the concentration of caustic soda vary between 2 and $5 \mathrm{~N}$.

In each of the procedures mentioned above neutralization is carried out hot, with oil at a temperature between $50-60^{\circ} \mathrm{C}$ and addition of caustic soda between $70-80^{\circ} \mathrm{C}$. 


\subsubsection{Chemical characteristics of the used oil}

Chemical characterization of the used oil, is presented in table 4

\begin{tabular}{|l|c|}
\hline \multicolumn{1}{|c|}{ FEATURES } & $\begin{array}{c}\text { OIL COLLECTED BY THE } \\
\text { HOTEL SECTOR }\end{array}$ \\
\hline Acidity $(\%)$ & 0.56 \\
\hline Moisture & 0.25 \\
\hline Viscosity at $37^{\circ} \mathrm{C}($ centistokes) & 44.78 \\
\hline Iodine index $\left(\mathrm{Cgl}_{2} / \mathrm{g}\right)$ & 108.22 \\
\hline Peroxide index (meq. Oxygen active/Kg of sample) & 16.61 \\
\hline Unsaponifiable material $(\%)$ & 1.70 \\
\hline Saponification index $(\mathrm{mg} \mathrm{KOH} / \mathrm{g})$ & 195.87 \\
\hline Ash $(\%)$ & 0.030 \\
\hline Refractive index $25^{\circ} \mathrm{C}$ & 1.4700 \\
\hline Density $15^{\circ} \mathrm{C}(\mathrm{g} / \mathrm{mL})$ & 0.9216 \\
\hline
\end{tabular}

Table 4. Characterization of cooking oil collected by the hotel sector (Source: Avalquímico Ltda.2010)

\section{Biodiesel production from used cooking oils}

According to table 5, the catalyst with higher industrial scaling, economic cost, high yields and short reaction time, is the alternative of basic catalysis, using sodium hydroxide. Although soap can be formed using sodium hydroxide in the transesterification reaction, this occurs if the content of free fatty acids is greater than $1 \%$ and the type of oil collected from the hotel sector has a percentage of acidity of $0.54 \%$, so it is not problem to use this type of catalyst for the biodiesel production.

\begin{tabular}{|c|c|c|c|}
\hline \multirow{2}{*}{ SELECTION PARAMETERS } & \multicolumn{3}{|c|}{ Comparison of alternatives } \\
\cline { 2 - 4 } & Alkaline & Heterogeneous & Acid \\
\hline Catalyst & NaOH & CaO & $\mathrm{H}_{2} \mathrm{SO}_{4}$ \\
\hline Alcohol & Methanol & Methanol & Methanol \\
\hline Scaling & High & Low & Low \\
\hline Catalyst separation & Low & High & Low \\
\hline By-products formation & Glycerin & Glycerin & Glycerin \\
\hline Environmental impact & Soap, pasty & & \\
\hline Cost & High & Low & High \\
\hline Availability & Medium & Low & Medium \\
\hline Catalyst concentration $(\% \mathrm{w} / \mathrm{w})$ & Low & Medium & High \\
\hline Molar ratio alcohol/oil & Medium & Low & High \\
\hline Temperature $\left({ }^{\circ} \mathrm{C}\right)$ & Low & High & Medium \\
\hline Yield & High & Low & Medium \\
\hline Reaction time (hours) & Low & Low & High \\
\hline Safety level & High & Low & High \\
\hline
\end{tabular}

Table 5. Comparison of alternatives for the biodiesel production. 
To select the best alternative for the biodiesel production are defined three ranges for the operation conditions to be used in the transesterification reaction (table 6).

\begin{tabular}{|c|c|c|c|}
\hline \multirow{2}{*}{$\begin{array}{c}\text { SELECTION } \\
\text { PARAMETERS }\end{array}$} & Low & Middle & High \\
\cline { 2 - 4 } & $0.2 \%-1 \%$ & $>1 \%-3 \%$ & $>3 \%-15 \%$ \\
\hline Catalyst concentration $(\% \mathrm{w} / \mathrm{w})$ & $3: 1-6: 1$ & $>6: 1-12: 1$ & $>12: 1-80: 1$ \\
\hline Molar ratio alcohol/oil & $50-60$ & $>60-100$ & $>100-200$ \\
\hline Temperature $\left({ }^{\circ} \mathrm{C}\right)$ & $20-70$ & $>70-90$ & $>90-100$ \\
\hline Yield $(\%)$ & $0.16-1$ & $>1-2$ & $>2-40$ \\
\hline Reaction time (hours) &
\end{tabular}

Table 6. Ranges established for the operation conditions of the transesterification reaction (Rojas \& Torres. 2009. pp 18).

\subsection{Experimental design}

It is a key to make a design from which the most appropriate values for each of the design factors can be established. The selected factors were: molar ratio alcohol/oil, percentage of catalyst, temperature and washing agent, where the first three are design variables and the latter is a design condition. Before starting the design is important defines the ranges and levels for these factors, for this reason, we search the experimental phase in scientific articles related to the project (table 7).

\begin{tabular}{|c|c|}
\hline DESIGN FACTORS & RANGE \\
\hline Molar ratio alcohol/oil & $6: 1-15: 1$ \\
\hline Catalyst Percentage $(\% \mathrm{wt})$. & $0,4-1$ \\
\hline Temperature $\left({ }^{\circ} \mathrm{C}\right)$ & $40-70$ \\
\hline Washing agent & Water $\left(40^{\circ} \mathrm{C}\right)$ - Acetic acid \\
\hline
\end{tabular}

Table 7. Ranges for the design factors

Based on the ranges set out in table 7 , we provide that the factorial design appropriate for the process is the factorial design $2 \mathrm{k}$, which can be solved by the technique of Yate contrasts which establish two levels for each of the design factors, these levels are high (+) and low (-) (see table 8)

\begin{tabular}{|c|c|c|}
\hline Design Factor & High level (+) & Low level (-) \\
\hline Molar ratio alcohol/oil & $9: 1$ & $6: 1$ \\
\hline Catalyst Percentage $(\% \mathrm{wt})$ & 0.7 & 0.5 \\
\hline Temperature $\left({ }^{\circ} \mathrm{C}\right)$ & 60 & 50 \\
\hline Washing agent & Acetic acid & Water $\left(40^{\circ} \mathrm{C}\right)$ \\
\hline
\end{tabular}

Table 8. Levels for each design factor

For the molar ratio alcohol/oil is found a ratio of $6: 1$ that is optimum for achieving high conversions, some articles display that lower ratio not is possible to reach a complete transesterification reaction. There are also good results with ratios ranging between 9:1 and 12:1, while if we use higher than 15:1 molar ratio there are difficulties in the separation of glycerin and methyl esters. 
For the catalyst concentration the values vary in a range of $0.4-2 \%$ being the concentration $1 \%$ better but the reaction yield is not very high.

For the design factorial mentioned we can set the number of trials, having clear that 2 is the number of levels and $\mathrm{k}$ is the number of factors, i.e. which has a total of $2^{4}$ treatments and is carried out a duplicated for each one, as should be taken into account the time limit and the project costs, which in total we have 16 experiments. Then is defined the signs matrix (table 9), where it is necessary to enumerate the trials and then is assigned a combination of treatments that aims to relate the design factors.

Consecutively is assigned the level for each combination, positive for the design factor that is being evaluated in the trial and negative for whose are not related. For this type of design the first trial has low levels and the final test has the higher levels.

\begin{tabular}{|c|c|c|c|c|c|}
\hline \multirow{2}{*}{ Trial } & \multirow{2}{*}{ Combination of Treatments } & \multicolumn{4}{|c|}{ Design Factors } \\
\cline { 2 - 6 } & & A & B & C & D \\
\hline 1 & 1 & - & - & - & - \\
\hline 2 & A & + & - & - & - \\
\hline 3 & B & - & + & - & - \\
\hline 4 & C & - & - & + & - \\
\hline 5 & D & - & - & - & + \\
\hline 6 & AB & + & + & - & - \\
\hline 7 & AC & + & - & + & - \\
\hline 8 & AD & + & - & - & + \\
\hline 9 & BC & - & + & + & - \\
\hline 10 & BD & - & + & - & + \\
\hline 11 & CD & - & - & + & + \\
\hline 12 & ABC & + & + & + & - \\
\hline 13 & ABD & + & + & - & + \\
\hline 14 & ACD & + & - & + & + \\
\hline 15 & BCD & - & + & + & + \\
\hline 16 & ABCD & + & + & + & + \\
\hline
\end{tabular}

Table 9. Matrix of signs

Performance is evaluated according to the treatments combination, considering that a duplicated is made by treatment. With data from the response variable, which is the yield, we carry out a statistical analysis by means of the ANOVA table or analysis of variance for data, which gives the more appropriate conditions for each factors of design and allows establishing that trials were the best.

For each main effect and interaction effect we have associated a single degree of freedom, so this is calculated using the following expression:

$$
G L_{i}=N_{\text {niveles }}^{0}-1
$$

Where: 
$i$ : is any combination of treatment

$N_{\text {levels }}^{o}=2$, because we have a high level and one low

To determine that interactions are significant an $\mathrm{f}$ for each source of variation is calculated and compared to $\mathrm{f}_{0,05}(1,16)=4,49$, with this we can determine in which region (probable region $\mathrm{RP}$ or critical region $\mathrm{RC}$ ) is each treatment and thus be able to establish that treatment is accepted or rejected with the help of figure 6.

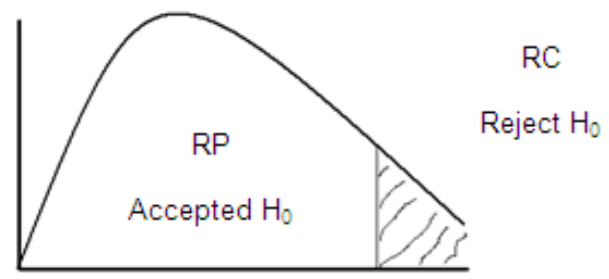

$0 \quad F \alpha$

Fig. 6. Function $\mathrm{f}$

\subsection{Experimental development at the laboratory level}

Table 10, shows the quantities determined at the laboratory level for each compound that is involved in the biodiesel production.

\begin{tabular}{|c|c|}
\hline \multicolumn{2}{|c|}{ AMOUNT OF REAGENTS } \\
\hline Waste cooking oil $(\mathrm{mL})$ & 150 \\
\hline Amount of methanol $(6: 1)(\mathrm{mL})$ & 40.63 \\
\hline Amount of methanol $(9: 1)(\mathrm{mL})$ & 60.95 \\
\hline Amount of $\mathrm{NaOH}$ grams $(0.5 \% \mathrm{p} / \mathrm{p})$ & 0.823 \\
\hline Amount of $\mathrm{NaOH}$ grams $(0.7 \% \mathrm{p} / \mathrm{p})$ & 1.105 \\
\hline Amount of $\mathrm{HCl}$ grams $(0.5 \% \mathrm{p} / \mathrm{p})$ & 1.466 \\
\hline Amount of $\mathrm{HCl}$ grams $(0.7 \% \mathrm{p} / \mathrm{p})$ & 2.053 \\
\hline
\end{tabular}

Table 10. Amount of reagents

First is the filtration of used oil, then mixing alcohol/catalyst to add it to the reactor which contains the oil at the temperature of the transesterification reaction, then is the separation of biodiesel and glycerin, washes the biodiesel and finally is the distillation of the biodiesel. "The dissolution is agitated at low rpm because that at high revolutions sodium hydroxide can be oxidized" (Arbeláez \& Rivera, 2007. pp45), should also be covered because amount of methanol due to its volatility can be lost. For the transesterification reaction are used reactors of four mouths with capacity of $500 \mathrm{~mL}$ and $1000 \mathrm{~mL}$, magnetic stirrers, plates of agitation, spiral capacitors, mercury thermometers, thermostat bath and temperature controller. Figure 7, shows the setup for the biodiesel production. 


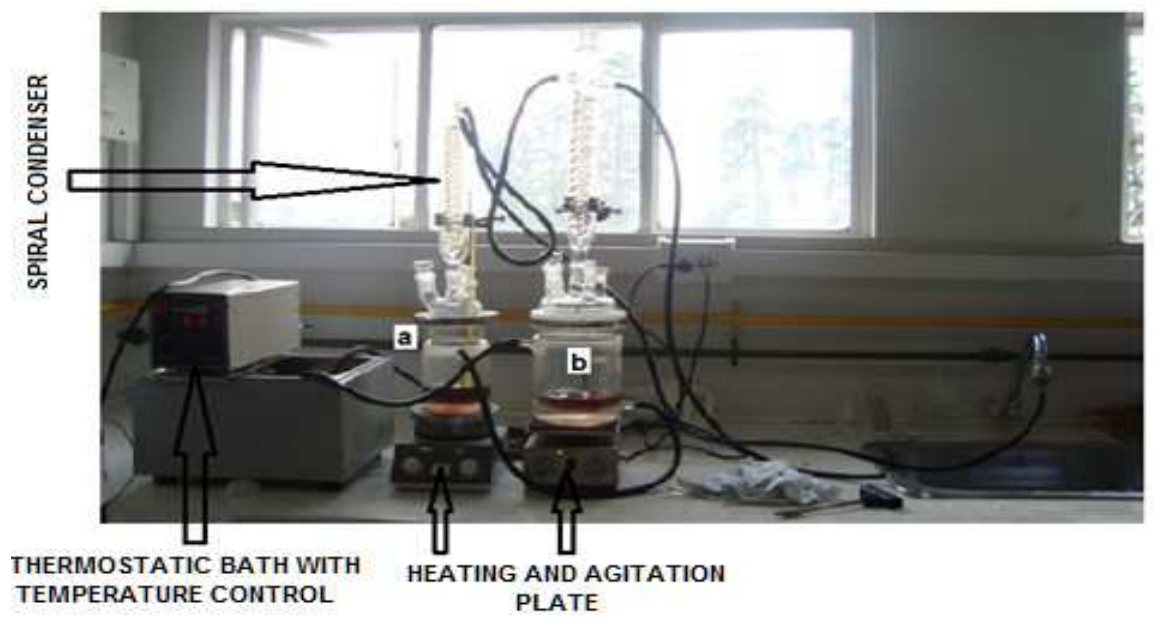

Fig. 7. Biodiesel production assembly: a) Reactor of $500 \mathrm{~mL}$ b) Reactor of $1 \mathrm{~L}$.

To carry out the transesterification reaction is loaded oil at the reactors and heated up to reaction temperature, while it reaches the temperature is made the mixture of the catalyst with alcohol, then it is added to the reactor. At the end of the reaction time is added $\mathrm{HCl}$ to 37 per cent in order to neutralize the reaction.

Completed reaction, the product is poured into the separation funnels and let a minimum time of 8 hours, to ensure good separation of the phases (Figure 8). Separation times were not equal for all runs varied between 10-24 hours.

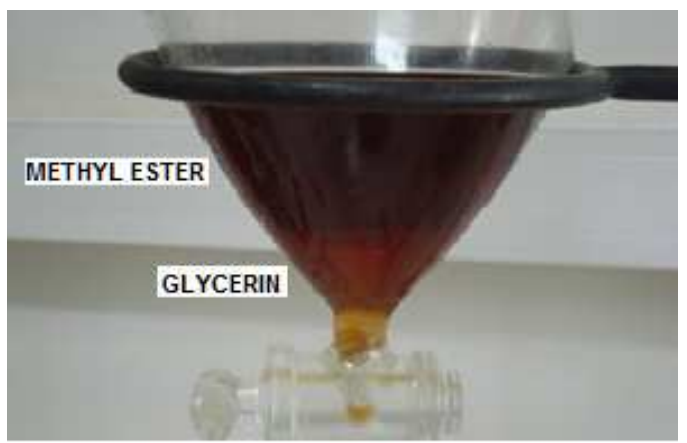

Fig. 8. Biodiesel-Glycerin separation

Once separate the glycerin from biodiesel, it is carried out the washing on the funnels. Separate the glycerin, the biodiesel must be washed because that may contain residues of catalyst, methanol, soaps and glycerides without reacting. Two types of washings are established according to the experimental design.

In one of the washing, water at $40{ }^{\circ} \mathrm{C}$ is used for three washes. Other tests of washing have been conducted with acetic acid $10 \% \mathrm{wt}$, where is used the same amount of used cooking oil; two washes are carried out with acid solution and the third is done with deionized water. 


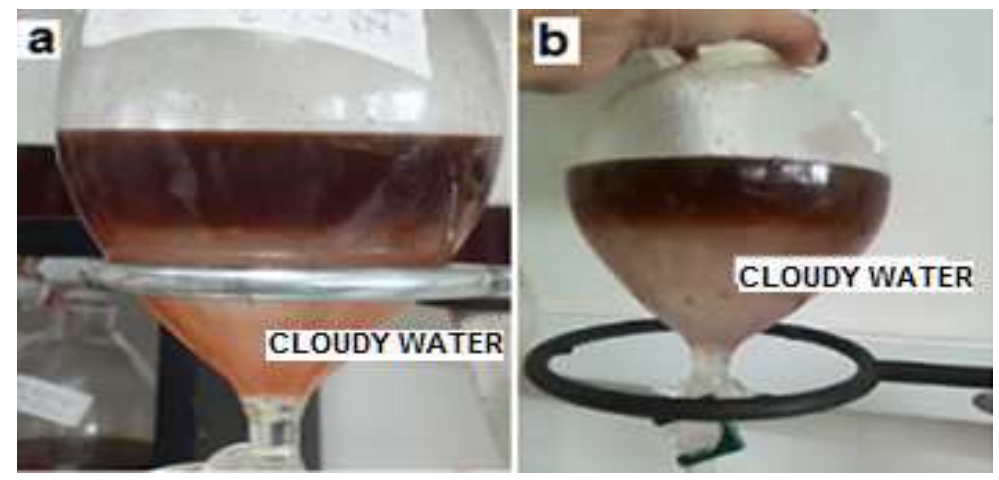

Fig. 9. First biodiesel wash: (a) Water at $40^{\circ} \mathrm{C}$ (b) acetic acid solution

The distillation is carried out at $40{ }^{\circ} \mathrm{C}$, temperature which is below the boiling point of methanol. The vacuum pump is used in order to minimize the time of distillation and vacuum trap is used to prevent waste of alcohol and water to the pump.

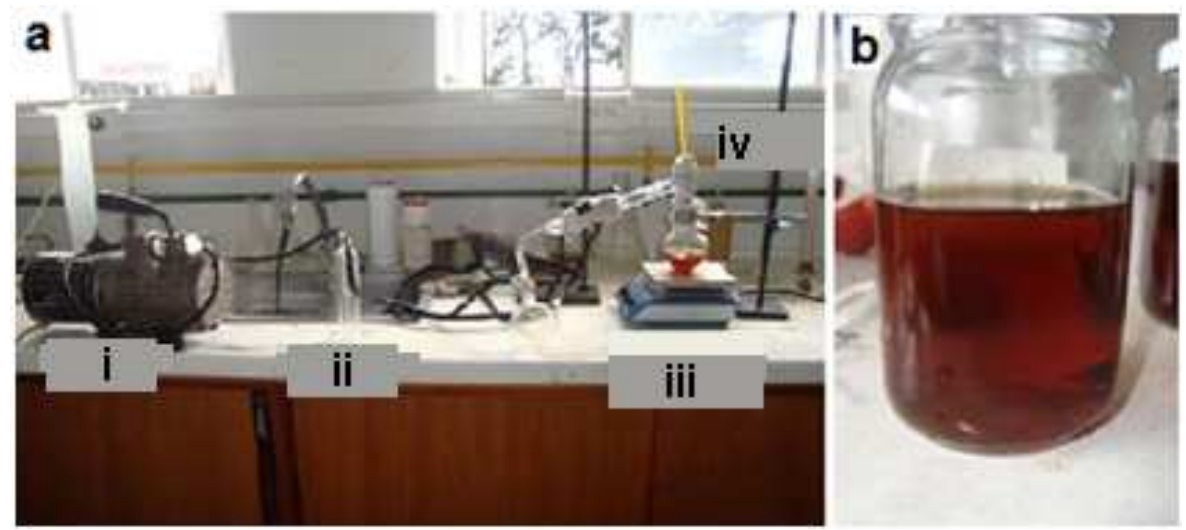

Fig. 10. Biodiesel distillation (a) Mounting: i. vacuum pump ii. Vacuum trap iii. Hot plate iv. Thermometer (b) Distilled biodiesel

\subsection{Results and analysis}

We show the results and analysis of tests conducted at the laboratory level, as its density and the analysis of variance. According to the literature retrieved biodiesel is "liquid, transparent and reddish color without any content of solids or gels" (Arbeláez \& Rivera, 2007. pp37).

Taking into account the results of the biodiesel appearance, it can be concluded that the catalyst percentage influences in the biodiesel stability because that similar conditions were equal in appearance. The majority of samples that had contained solids, gels and their appearance was opaque, were the samples where used $0.5 \% \mathrm{NaOH}$.

Opaque samples as the 3, 4 and 7 are because have much water content, this might be for the washes with water at $40^{\circ} \mathrm{C}$ and its water content was increased. Opacity is an indicator that the methyl esters have presence of water. 
The table 11 shows the densities for each test sample.

\begin{tabular}{|c|c|c|}
\hline & DUPLICATE 1 & DUPLICATE 2 \\
\hline TEST & $\begin{array}{c}\text { Biodiesel density } \\
(\mathrm{g} / \mathrm{ml})\end{array}$ & $\begin{array}{c}\text { Biodiesel density } \\
(\mathrm{g} / \mathrm{ml})\end{array}$ \\
\hline 1 & 0,902 & 0,910 \\
\hline 2 & 0,902 & 0,877 \\
\hline 3 & 0,867 & 0,887 \\
\hline 4 & 0,893 & 0,881 \\
\hline 5 & 0,897 & 0,903 \\
\hline 6 & 0,885 & 0,887 \\
\hline 7 & 0,883 & 0,906 \\
\hline 8 & 0,906 & 0,860 \\
\hline 9 & 0,871 & 0,887 \\
\hline 10 & 0,885 & 0,893 \\
\hline 11 & 0,914 & 0,906 \\
\hline 12 & 0,897 & 0,891 \\
\hline 13 & 0,900 & 0,895 \\
\hline 14 & 0,885 & 0,875 \\
\hline 15 & 0,883 & 0,862 \\
\hline 16 & 0,873 & 0,891 \\
\hline
\end{tabular}

Table 11. Density for each sample

The biodiesel density according to standard ASTM D-1298 must be in a range of (0.86 - 0.90 $\mathrm{g} / \mathrm{ml}$ ), the density does not guarantee that retrieved biodiesel is of good quality, but is taken to compare samples with each other, due there is evidence that satisfy with the provided density but its appearance is not adequate or are samples which do not comply with the permitted density value but its appearance is appropriated. As for example, the duplicate 2 from sample 1 exceeds the density range allowed for biodiesel, but the appearance fulfill with the stipulated features. For the sample 11, both the duplicate 1 and the 2 exceed the density level and its appearance is a little opaque.

Samples 11 and 12 are in the density range allowed but the appearance does not meet any features because have high solids content and are highly opaque.

Some samples contain solids and do not fulfill with the physical characteristics of biodiesel, have a density within the level agreed by the ASTM D-1298 standard for a biodiesel of good quality, which must be due to that the solids are smaller proportion than the liquid phase that is rich in methyl esters.

It can be concluded that the density and appearance analysis are not reliable parameters to determine the biodiesel quality. For this reason, based on the order of the table 12, we can determine the variable response (table 13), which is expressed as the ratio between the mass of the biodiesel produced and the mass of oil used for the production (productivity per cent). 


\begin{tabular}{|c|c|c|c|c|c|}
\hline \multirow{2}{*}{ TEST } & COMBINATION OF & \multicolumn{4}{|c|}{ DESIGN FACTORS } \\
\cline { 3 - 6 } & TREATMENTS & A & B & C & D \\
\hline 1 & 1 & $6: 1$ & 0,5 & 50 & Water $\left(40^{\circ} \mathrm{C}\right)$ \\
\hline 2 & $\mathrm{~A}$ & $9: 1$ & 0,5 & 50 & Water $\left(40^{\circ} \mathrm{C}\right)$ \\
\hline 3 & $\mathrm{~B}$ & $6: 1$ & 0,7 & 50 & Water $\left(40^{\circ} \mathrm{C}\right)$ \\
\hline 4 & $\mathrm{AB}$ & $9: 1$ & 0,7 & 50 & Water $\left(40^{\circ} \mathrm{C}\right)$ \\
\hline 5 & $\mathrm{C}$ & $6: 1$ & 0,5 & 60 & Water $\left(40^{\circ} \mathrm{C}\right)$ \\
\hline 6 & $\mathrm{AC}$ & $9: 1$ & 0,5 & 60 & Water $\left(40^{\circ} \mathrm{C}\right)$ \\
\hline 7 & $\mathrm{BC}$ & $6: 1$ & 0,7 & 60 & Water $\left(40^{\circ} \mathrm{C}\right)$ \\
\hline 8 & $\mathrm{ABC}$ & $9: 1$ & 0,7 & 60 & Water $\left(40^{\circ} \mathrm{C}\right)$ \\
\hline 9 & $\mathrm{D}$ & $6: 1$ & 0,5 & 50 & Acetic Acid $(\mathrm{T} \mathrm{amb})$ \\
\hline 10 & $\mathrm{AD}$ & $9: 1$ & 0,5 & 50 & Acetic Acid $(\mathrm{T} \mathrm{amb})$ \\
\hline 11 & $\mathrm{BD}$ & $6: 1$ & 0,7 & 50 & Acetic Acid $(\mathrm{T} \mathrm{amb})$ \\
\hline 12 & $\mathrm{ABD}$ & $9: 1$ & 0,7 & 50 & Acetic Acid $(\mathrm{T} \mathrm{amb})$ \\
\hline 13 & $\mathrm{CD}$ & $6: 1$ & 0,5 & 60 & Acetic Acid $(\mathrm{T} \mathrm{amb})$ \\
\hline 14 & $\mathrm{ACD}$ & $9: 1$ & 0,5 & 60 & Acetic Acid $(\mathrm{T} \mathrm{amb})$ \\
\hline 15 & $\mathrm{BCD}$ & $6: 1$ & 0,7 & 60 & Acetic Acid $(\mathrm{T} \mathrm{amb})$ \\
\hline 16 & $\mathrm{ABCD}$ & $9: 1$ & 0,7 & 60 & Acetic Acid $(\mathrm{T} \mathrm{amb})$ \\
\hline
\end{tabular}

Table 12. Rearranged experimental matrix

\begin{tabular}{|c|c|c|c|}
\hline \multirow{2}{*}{ TEST } & COMBINATION OF & \multicolumn{2}{|c|}{ PRODUCTIVITY (\%) } \\
\cline { 3 - 4 } & TREATMENTS & DUPLICATE 1 & DUPLICATE 2 \\
\hline 1 & 1 & 70 & 44,9 \\
\hline 2 & $\mathrm{~A}$ & 79,5 & 74,3 \\
\hline 3 & $\mathrm{~B}$ & 85,6 & 84,5 \\
\hline 4 & $\mathrm{AB}$ & 93,7 & 93,9 \\
\hline 5 & $\mathrm{C}$ & 69,4 & 68,4 \\
\hline 6 & $\mathrm{AC}$ & 62,3 & 88,2 \\
\hline 7 & $\mathrm{BC}$ & 64,5 & 62,6 \\
\hline 8 & $\mathrm{ABC}$ & 88,7 & 85,5 \\
\hline 9 & $\mathrm{D}$ & 62,1 & 63,1 \\
\hline 10 & $\mathrm{AD}$ & 89,5 & 60,7 \\
\hline 11 & $\mathrm{BD}$ & 76,2 & 80,7 \\
\hline 12 & $\mathrm{ABD}$ & 88,9 & 88,5 \\
\hline 13 & $\mathrm{CD}$ & 61,3 & 57,5 \\
\hline 14 & $\mathrm{ACD}$ & 81,2 & 80,3 \\
\hline 15 & $\mathrm{BCD}$ & 74,8 & 71,8 \\
\hline 16 & $\mathrm{ABCD}$ & 86,2 & 81,8 \\
\hline
\end{tabular}

Table 13. Reaction productivity

We carry out the ANOVA statistical analysis (table 14) and the test of hypothesis (table 15). 


\begin{tabular}{|c|c|c|c|c|c|}
\hline $\begin{array}{c}\text { COMBINATION } \\
\text { OF TREATMENTS }\end{array}$ & EFECTS & $\begin{array}{c}\text { SQUARES } \\
\text { SUM }\end{array}$ & $\begin{array}{c}\text { FREEDOM } \\
\text { DEGREES }\end{array}$ & $\begin{array}{c}\text { MEAN } \\
\text { SQUARE }\end{array}$ & f CALCULATED \\
\hline A & 14,1125 & 1593,30 & 1 & 1593,30 & 22,78 \\
\hline B & 12,2 & 1190,72 & 1 & 1190,72 & 17,02 \\
\hline C & $-3,225$ & 83,205 & 1 & 83,21 & 1,19 \\
\hline D & $-0,7125$ & 4,06125 & 1 & 4,06 & 0,06 \\
\hline AB & & & & & \\
\hline AC & $-0,8$ & 5,12 & 1 & 5,12 & 0,07 \\
\hline AD & $-0,4125$ & 15,125 & 1 & 15,12 & 0,22 \\
\hline BC & $-6,2875$ & 316,26125 & 1 & 1,36 & 0,02 \\
\hline BD & $-0,55$ & 2,42 & 1 & 2,42 & 4,52 \\
\hline CD & 1,375 & 15,125 & 1 & 15,13 & 0,03 \\
\hline ABC & 2,437500 & 47,531250 & 1 & 47,53 & 0,22 \\
\hline ABD & $-2,425000$ & 47,045000 & 1 & 47,05 & 0,68 \\
\hline ACD & 0,950000 & 7,220000 & 1 & 7,22 & 0,67 \\
\hline BCD & 3,212500 & 82,561250 & 1 & 82,56 & 1,1803 \\
\hline ABCD & & & & & \\
\hline ERROR & $-4,5375$ & 164,71125 & 1 & 164,71 & 2,35 \\
\hline TOTAL & & 1119,21 & 16 & 69,950625 & \\
\hline
\end{tabular}

Tablle 14. ANOVA TABLE

\begin{tabular}{|c|c|c|c|c|}
\hline $\begin{array}{c}\text { COMBINATION } \\
\text { OF TREATMENTS }\end{array}$ & EFECTS & f CALCULATED & f alfa & DECISION \\
\hline $\mathrm{A}$ & 14,1125 & 22,77751271 & 4,49 & NOT ACCEPTED \\
\hline $\mathrm{B}$ & 12,2 & 17,02229251 & 4,49 & NOT ACCEPTED \\
\hline $\mathrm{C}$ & $-3,225$ & 1,189481867 & 4,49 & ACCEPTED \\
\hline $\mathrm{D}$ & $-0,7125$ & 0,058058809 & 4,49 & ACCEPTED \\
\hline $\mathrm{AB}$ & $-0,8$ & 0,073194485 & 4,49 & ACCEPTED \\
\hline $\mathrm{AC}$ & 1,375 & 0,216223944 & 4,49 & ACCEPTED \\
\hline $\mathrm{AD}$ & $-0,4125$ & 0,019460155 & 4,49 & ACCEPTED \\
\hline $\mathrm{BC}$ & $-6,2875$ & 4,521206923 & 4,49 & NOT ACCEPTED \\
\hline $\mathrm{BD}$ & $-0,55$ & 0,034595831 & 4,49 & ACCEPTED \\
\hline $\mathrm{CD}$ & 1,375 & 0,216223944 & 4,49 & ACCEPTED \\
\hline & & & & \\
\hline $\mathrm{ABC}$ & 2,437500 & 0,679497145 & 4,49 & ACCEPTED \\
\hline $\mathrm{ABD}$ & $-2,425000$ & 0,672545814 & 4,49 & ACCEPTED \\
\hline $\mathrm{ACD}$ & 0,950000 & 0,103215661 & 4,49 & ACCEPTED \\
\hline $\mathrm{BCD}$ & 3,212500 & 1,180278947 & 4,49 & ACCEPTED \\
\hline $\mathrm{ABCD}$ & $-4,5375$ & 2,354678747 & 4,49 & ACCEPTED \\
\hline
\end{tabular}

Table 15. Hypothesis test 
The factor A, the molar ratio alcohol/oil, has a significant effect on the reaction productivity, since the effect is positive by increasing the molar ratio increases productivity, for this reason the highest 9:1 ratio is selected.

The factor $B$, the catalyst concentration has a significant effect on the reaction productivity so increasing the catalyst concentration increases the reaction productivity for this reason we select $0.7 \% \mathrm{w} / \mathrm{w}$. The factor $\mathrm{C}$, the reaction temperature has no significant effect, but is recommended to work with the lowest level, i.e. at a temperature $50{ }^{\circ} \mathrm{C}$ to prevent a further loss of methanol due to its volatility. The factor $\mathrm{D}$, the washing agent has no significant effect because the effect is negative, we select the low level (-) water at $40{ }^{\circ} \mathrm{C}$.

The combination of treatments $\mathrm{AB}, \mathrm{AC}, \mathrm{AD}, \mathrm{CD}, \mathrm{ABC}, \mathrm{ABD}, \mathrm{ACD}, \mathrm{BCD}, \mathrm{ABCD}$, do not has significant effects on the reaction productivity. The treatment combination $B C$ has significant effects on the reaction productivity, so it is advisable to work with levels higher for each factor, catalyst concentration of $0.7 \% \mathrm{p} / \mathrm{p}$ and reaction temperature of $50{ }^{\circ} \mathrm{C}$.

Table 16, shows the made characterization of the sample obtained to a molar ratio alcohol/oil 9:1, catalyst concentration $0.7 \% \mathrm{w} / \mathrm{w}$, reaction temperature of $50{ }^{\circ} \mathrm{C}$ and water at $40{ }^{\circ} \mathrm{C}$ as washing agent that is the biodiesel with a best properties.

\begin{tabular}{|c|c|c|c|}
\hline Properties & Unit & Results & Standard (ASTM D-6751) \\
\hline Density at $15.6^{\circ} \mathrm{C}$ & $\mathrm{kg} / \mathrm{m}^{3}$ & 889.9 & $860-900$ \\
\hline Grades API & & 27 & Minimum 32 \\
\hline Cinematic Viscosity at $40^{\circ} \mathrm{C}$ & Cst & 5.21 & $1.9-6$ \\
\hline Cetane index & & 48 & Minimum 47 \\
\hline Caloric value & $\mathrm{J} / \mathrm{g}$ & $40,873.00$ & $37,216.00$ \\
\hline Temperature $90 \%$ distilled & ${ }^{\circ} \mathrm{C}$ & 332 & Maximum 360 \\
\hline
\end{tabular}

Table 16. Properties of the biodiesel sample to the best conditions

API gravity for the biodiesel retrieved is in a range of 32-34 degrees API, the analyzed sample showed a value below the reported ranges, which indicates that the biodiesel retrieved from this sample has a high density, which as we see in the analysis is of 889.9 $\mathrm{kg} / \mathrm{m}^{3}$, taking into account that the API gravity is inversely proportional to the density. As for the other properties analyzed, these can be found within the values reported by the literature, which guarantees the quality of biodiesel.

\section{Conclusions}

We can conclude that using acetic acid or water as a washing agent does not affect the reaction productivity, similar to the reaction temperature has no effect on the variable response within the levels used in the research. The unique variables that affect the biodiesel production are the catalyst concentration and the molar ratio alcohol/oil.

According with the above, the best conditions of operation are:

- Molar ratio alcohol/aceite: 9:1

- Catalyst concentration of: $0.7 \% \mathrm{w} / \mathrm{w}$

- $\quad$ Reaction temperature: $50^{\circ} \mathrm{C}$

- Washing agent: water at $40^{\circ} \mathrm{C}$

\section{Acknowledgment}

This research was carried out in the laboratory of the Natural Resources Energetic Exploitation research group of the Chemistry Department's National University of 
Colombia and sponsored for the research group CDM \& EG of the Mechanical Department of Engineering Faculty of the National University of Colombia.

\section{References}

Arbeláez, M., Rivera, M. (2007). Diseño conceptual de un proceso para la obtención de biodiesel a partir de algunos aceites vegetales colombianos. Universidad Eafit. Medellín.

Benjumea P, Benavides A Y Pashova V. (2007). El biodiesel de aceite de higuerilla como combustible alternativo para motores diesel, Universidad Nacional De Colombia Sede Medellín.

Bournay L, Casanave D, Chodorge J, Delfort D Y Hillion G. (2005), new heterogeneous process for biodiesel production: a way to improve the quality and the value of the crude glycerin produced by biodiesel plants, France.

Chen G, Meng X Y Wang Y. (2008). Biodiesel production from waste cooking oil via alkali catalyst and its engine test, China Architecture Design \& Research Group, Beijing, China.

Cujia G., Bula A. (2010). Potencial obtención de gas de sintesis para la producción de metanol a partir de la gasificación de residuos de palma africana. Asociación Interciencia Venezuela.

Diaz-Zorita, M., Et Al., El cultivo De Girasol, In: ASAGIR, 2003, $<$ Http:/ /Www.Asagir.Org.Ar/Publicaciones/Cuadernillo_Web.Pdf $>$

Ente Regional De La Energía De Castilla Y León (EREN) (2003). Plan piloto de recogida de aceites de cocina usados para la producción de biodiesel. España.

Errazu A, Marchetti J Y Miguel V.(2005). Possible methods for biodiesel production, Planta Piloto De Ingeniería Química, Argentina.

FEDEPALMA(n.d.), Biodiesel, In: FEDEPALMA. 20 of june of 2011, Available from: $<$ Http://Www.Fedepalma.Org/>

Girón E, Rojas A Y Torres Harlen. (2009).variables de operación en el proceso de transesterificación de aceites vegetales: una revisión. In: Catálisis Química, Vol 29 No 3.

Guan G, Kusakabe K Y Yamasaki S.(2009). Tri-potassium phosphate as a solid catalyst for biodiesel production from waste cooking oil, Department Of Living Environmental Science, Fukuoka Women's University,

INFOAGRO, El Cultivo Del Girasol ( $1^{\text {a }}$ Parte $) 20$ of june of 2011, In: INFOAGRO, Available from: <Http:/ /Www.Infoagro.Com/Herbaceos/Oleaginosas/Girasol.Htm>

Iriarte, L. El Cultivo De Colza En Argentina, In: ANTI, 20 of june of 2011, Available from: <Http://Www.Inta.Gov.Ar/Ediciones/Idia/Oleaginosa/Colza01.Pdf>

Liu P, Ou S, Wang, Y. Zhang Z. (2006a). Preparation of biodiesel from waste cooking oil via twostep catalyzed process, Department Of Food Science And Engineering.

Liu P, Ou S, Tang S, Wang Y Y Xue F.(2006b) comparison of two different processes to synthesize biodiesel by waste cooking oil, Department Of Food Science And Engineering, Jinan University.

Peisch, S. (n.d.). Aguas Usadas En Puerto Rico: Amenaza A La Salud Publica Y Al Ambiente, In: Datos Marinos \#54. 20 of june of 2011, Available from: <Http://Www.Seagrantpr.Org/Catalog/Files/Fact_Sheets/54-Aguas-Usadas-DePr.Pdf $>$

Rojas A Y Torres H. (2009). Variables de operación en el proceso de transesterificación de aceites vegetales: una revisión In: Catálisis Química.

Lles M, Pires E, Royo C. (2008). Estudio de catalizadores heterogéneos en la síntesis de biodiesel a partir de aceite de girasol. 


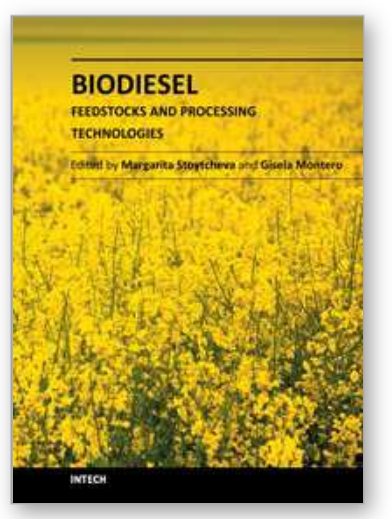

\author{
Biodiesel - Feedstocks and Processing Technologies \\ Edited by Dr. Margarita Stoytcheva
}

ISBN 978-953-307-713-0

Hard cover, 458 pages

Publisher InTech

Published online 09, November, 2011

Published in print edition November, 2011

The book "Biodiesel: Feedstocks and Processing Technologies" is intended to provide a professional look on the recent achievements and emerging trends in biodiesel production. It includes 22 chapters, organized in two sections. The first book section: "Feedstocks for Biodiesel Production" covers issues associated with the utilization of cost effective non-edible raw materials and wastes, and the development of biomass feedstock with physical and chemical properties that facilitate it processing to biodiesel. These include Brassicaceae spp., cooking oils, animal fat wastes, oleaginous fungi, and algae. The second book section: "Biodiesel Production Methods" is devoted to the advanced techniques for biodiesel synthesis: supercritical transesterification, microwaves, radio frequency and ultrasound techniques, reactive distillation, and optimized transesterification processes making use of solid catalysts and immobilized enzymes. The adequate and upto-date information provided in this book should be of interest for research scientist, students, and technologists, involved in biodiesel production.

\title{
How to reference
}

In order to correctly reference this scholarly work, feel free to copy and paste the following:

Carlos A. Guerrero F., Andrés Guerrero-Romero and Fabio E. Sierra (2011). Biodiesel Production from Waste Cooking Oil, Biodiesel - Feedstocks and Processing Technologies, Dr. Margarita Stoytcheva (Ed.), ISBN: 978953-307-713-0, InTech, Available from: http://www.intechopen.com/books/biodiesel-feedstocks-andprocessing-technologies/biodiesel-production-from-waste-cooking-oil

\section{INTECH}

open science | open minds

\section{InTech Europe}

University Campus STeP Ri

Slavka Krautzeka 83/A

51000 Rijeka, Croatia

Phone: +385 (51) 770447

Fax: +385 (51) 686166

www.intechopen.com

\section{InTech China}

Unit 405, Office Block, Hotel Equatorial Shanghai

No.65, Yan An Road (West), Shanghai, 200040, China

中国上海市延安西路 65 号上海国际贵都大饭店办公楼 405 单元

Phone: +86-21-62489820

Fax: $+86-21-62489821$ 
(C) 2011 The Author(s). Licensee IntechOpen. This is an open access article distributed under the terms of the Creative Commons Attribution 3.0 License, which permits unrestricted use, distribution, and reproduction in any medium, provided the original work is properly cited. 